Goldschmidt 2021 Abstract

https://doi.org/10.7185/gold2021.7152

\section{Metasomatized mantle xenoliths from Canastra-1 kimberlite, southern edge of the São Francisco Craton}

\author{
LUISA GOMES BRAGA ${ }^{1}$, TIAGO JALOWITZKI ${ }^{1}$, \\ MARCELO PERES ROCHA ${ }^{1}$, FERNANDA GERVASONI ${ }^{2}$, \\ MAURIZIO MAZZUCCHELLI ${ }^{3}$, TOMMASO \\ GIOVANARDI $^{3}$, EDUARDO NOVAIS RODRIGUES ${ }^{1}$, \\ MARINA DALLA COSTA ${ }^{4}$, REINHARDT ADOLFO FUCK ${ }^{1}$, \\ GEORGINA MARIANELA RUBIANO ${ }^{5}$, GUSTAVO \\ WALTER BERTOTTO 5 AND ROBERTO VENTURA \\ SANTOS $^{1}$ \\ ${ }^{1}$ Universidade de Brasília (UnB) \\ ${ }^{2}$ Universidade Federal de Goiás (UFG) \\ ${ }^{3}$ Università degli Studi di Modena e Reggio Emilia \\ ${ }^{4}$ Agência Nacional de Mineração \\ ${ }^{5}$ CONICET - Universidad Nacional de La Pampa \\ Presenting Author: luisagbraga@gmail.com
}

The diamond-bearing Canastra-1 kimberlite represents a Cretaceous intrusion that belongs to the Alto Paranaíba Igneous Province (APIP), Brazil. This kimberlite hosts mantle xenoliths including garnet-bearing lherzolites, websterites (two samples are amphibole-bearing), clinopyroxenites and one eclogite. Magnesium number (Mg\#) of lherzolitic olivine (88-91), orthopyroxene (90-92) and clinopyroxene (89-91) are typical of mantle origin. Minerals from the hydrated websterites contain lower $\mathrm{Mg} \#($ opx $=74-75$; cpx $=78-79)$ than the anhydrous ones $($ opx $=90 ; c p x=89)$, indicating a cumulate origin for these samples. The clinopyroxene Mg\# of clinopyroxenites is low (8687), except for one sample that contains high $\mathrm{Mg \#} \mathrm{(90).} \mathrm{The} \mathrm{Mg} \#$ of eclogite omphacite is 87. Clinopyroxenes of the hydrated websterites show high $\mathrm{CaO}\left(>21\right.$ wt.\%) and $\mathrm{Al}_{2} \mathrm{O}_{3}$ (>5 wt.\%) contents coupled with low $\mathrm{MgO}(<14$ wt.\%), defining a trend in which $\mathrm{CaO}$ and $\mathrm{Al}_{2} \mathrm{O}_{3}$ contents decrease and $\mathrm{MgO}$ increase, characteristic of partial melting process. Pyrope endmember in garnets decreases from lherzolite (71-76) to anhydrous websterite (70-72), clinopyroxenite (62-69), eclogite (57) and hydrated websterite (42-46). The rare earth element (REE) patterns of clinopyroxenes display variable enrichment in light-REE (LREE) related to heavy-REE (HREE) $\left(\mathrm{Ce} / \mathrm{Yb}_{\mathrm{N}}=9.1-60.9\right)$, which indicate cryptic metasomatism. Garnets show normal REE pattern characterized by the domain of high HREE and gentle decrease of LREE $\left(\mathrm{Ce} / \mathrm{Yb}_{\mathrm{N}}<0.32\right)$. Representative temperature (T) and pressure (P) estimates demonstrate that lherzolites, anhydrous websterites and clinopyroxenites represent the deepest mantle column of Canastra- 1 lithosphere $\left(\mathrm{T}=1262-1338^{\circ} \mathrm{C} ; \mathrm{P}=\right.$ 5.0-5.5 GPa), whereas hydrous websterites $\left(\mathrm{T}=887-926^{\circ} \mathrm{C} ; \mathrm{P}=\right.$ 2.7-3.3 GPa $)$ and eclogite $\left(\mathrm{T}=972{ }^{\circ} \mathrm{C} ; \mathrm{P}=4.4 \mathrm{GPa}\right)$ samples are shallower. Therefore, we propose that cryptic metasomatism recorded by the lithospheric mantle beneath Canastra- 1 occurred due to the collision between the São Francisco Craton and the Paranapanema Block during the Neoproterozoic. The lowvelocity anomaly observed in the seismic tomographic data corroborates the high temperature estimates observed in the deeper xenoliths and it might be related to the lithospheric thinning and consequent asthenosphere upwelling in the Brasília Mobile Belt or could be associated to a Cretaceous fossil plume. 